\title{
Islamisasi Pengetahuan dan Model Pengembangannya pada Madrasah
}

\author{
Mukhibat \\ STAIN Ponorogo \\ Email: mukhibat@yahoo.co.id
}

\begin{abstract}
Madrasah in Indonesia have exciting development because of its integration with modernity and political support of the state that aligned with the public schools. However, it is recognized that the model of madrasah education in the country's legislation, led to dualism education system in Indonesia, which has not been resolved until now. The problem is a challenge in realizing the ideal madrasah. Through a historical-philosophical approach, this study examines the redefinition of the Islamization of knowledge by tracing historically the initial idea of Islamization of knowledge in responding to the challenges facing the madrasah. Through critical analysis examines the implications of the redefinition of the Islamization of knowledge and development models at the madrasah. There are at least three models of Islamization of knowledge that can be developed in the development and empowerment of the madrasah, the purification of the model, the model of modernization, and the model of Islamic neo-modernism.
\end{abstract}

Keywords : Islamization of knowledge,madrasah, modernization.

\begin{abstract}
Abstrak
Madrasah di Indonesia mengalami perkembangan menarik karena integrasinya dengan modernitas serta dukungan politik negara sehingga sejajar dengan sekolah umum. Namun demikian, diakui bahwa model pendidikan madrasah di dalam perundang-undangan negara, memunculkan dualisme sistem pendidikan di Indonesia yang belum dapat diselesaikan hingga sekarang. Problem tersebut menjadi tantangan tersendiri dalam mewujudkan madrasah yang ideal. Melalui pendekatan historis-filosofis, penelitian ini mengkaji tentang redefinisi Islamisasi pengetahuan dengan melakukan penelusuran historis terhadap gagasan awal Islamisasi, dalam merespons tantangan yang dihadapi madrasah. Melalui analisis kritis tersebut dikaji implikasi redefinisi Islamisasi pengetahuan dan model pengembangannya pada madrasah. Setidaknya ada tiga model Islamisasi pengetahuan yang dapat dikembangkan dalam pengembangan dan pemberdayaan madrasah, yaitu model purifikasi, model modernisasi, dan model neo-modernisme Islam.
\end{abstract}

Kata kunci: Islamisasi pengetahuan, madrasah, modernisasi 


\section{A. Pendahuluan}

Sebelum memasuki pembahasan topik tersebut di atas sebaiknya kalau dimulai dengan deskripsi jawaban yang sifatnya hipotesis atas pertanyaan: Apakah yang menjadi faktor determinan, sehingga pendidikan Islam mampu survival dalam sejarah yang begitu panjang sampai saat ini? Faktor determinan itu terletak pada kepiawaian pendidikan Islam dalam mengombinasikan dua hal: Pertama, karena secara konsisten berpegang teguh pada tradisi Keislamanya. Kedua, memiliki sikap positif terhadap perubahan yang terjadi di sekitarnya, terutama sejak disahkannya UU Sistem Pendidikan Nasional No 20 Tahun 2003 yang menandakan bahwa eksistensi madrasah sudah cukup kuat beriringan dengan sekolah umum. Kepiawaian tersebut tampak adanya proses dinamika, adaptasi, antisipasi, respons yang tinggi terhadap kemajuan zaman dan madrasah sudah mampu keluar dari sifat eksklusivisme.

Namun dalam perkembangannya, madrasah lebih banyak menikmati pengakuan peran kuantitatif dari masyarakat maupun pemerintah daripada pengakuan kualitatif. Pengakuan peran kuantitatif tersebut menjadikan parameter pendidikan lebih banyak tergantung pada political will pemerintah. Madrasah mau tidak mau harus menerima modernisasi yang berdampak bergesernya paradigma dalam kerangka memenuhi kebutuhan dan tuntutan perubahan. Bahkan tidak jarang banyak yang menyatakan bahwa modernisasi madrasah lebih mudah dipahami sebatas pengalihan konsentrasi siswa dan ketekunan mempelajari agama, menjadi kesungguhan mempelajari mata pelajaran umum. Pembaharuan pada madrasah terkesan potong kompas, yakni ingin langsung memasukkan ilmu-ilmu umum tanpa mempertimbangkan khazanah intelektual muslim. Hal ini memperburuk kebijakan Kemenag melalui Surat Edaran Dirjen Pendis No. Dj 11/PP.00/ED681/2006 tentang pelaksanaan Standar Isi justru menutup peluang MAK sebagai warisan kekhasan madrasah menjadi UPT tersendiri atau satuan pendidikan tingkat menengah. ${ }^{1}$

Diakui bahwa model pendidikan madrasah di dalam perundang-undangan negara, memunculkan dualisme sistem Pendidikan di Indonesia yang belum dapat diselesaikan hingga sekarang. Dualisme ini tidak hanya berkenaan dengan sistem pengajarannya

\footnotetext{
${ }^{1}$ Nunu Ahmad, dkk, Spektrum Baru Pendidikan Madrasah, (Jakarta: Puslitbang Kemenag RI, 2010), hlm. 11.
} 
tetapi juga menjurus pada keilmuannya. Pola pikir yang sempit cenderung memunculkan dikotomi epistemologis-teoritis dan stagnasi konsep pendidikan Islam. Problem tersebut menjadi tantangan tersendiri dalam mewujudkan pendidikan Islam yang ideal. Madrasah tampak berada dalam persimpangan jalan antara mempertahankan tradisi dan mengadopsi perkembangan baru.

Melalui pendekatan historis-filosofis, penelitian ini mengkaji tentang redefinisi Islamisasi pengetahuan dengan melakukan penelusuran historis terhadap gagasan awal Islamisasi pengetahuan dalam merespons tantangan yang dihadapi pendidikan Islam. Lewat analisis kritis tersebut dikaji implikasi redefinisi Islamisasi pengetahuan dan model pengembangannya pada madrasah.

\section{B. Gagasan Islamisasi Pengetahuan}

Diskursus Islamisasi pengetahuan ternyata masih cukup hangat dibicarakan, setelah lahirnya berbagai bentuk madrasah (MA Umum, MA Model, MA Keterampilan, MAK, MA Kejuruan, dan sedang hangat dibicarakan adalah Madrasah terpadu), ${ }^{2}$ apalagi setelah lahirnya berbagai Universitas Islam Negeri (UIN), yang kehadirannya dituntut untuk bisa tampil beda dengan sekolah dan universitas lainnya. Namun kehadirannya itu, sering timbul pertanyaan di masyarakat: apa sebenarnya yang membedakan antara lembaga-lembaga pendidikan di atas dengan lembaga pendidikan lainnya yang telah berkembang jauh sebelumnya? Jika tidak ada distingsi yang jelas untuk apa berbagai bentuk madrasah dan UIN didirikan, jangan-jangan justru malah menambah beban bagi pemerintah dan masyarakat.

Pertanyaan tersebut agaknya bernada sinis, namun hal itu adalah wajar bagi yang belum memahami hakikat atas kehadiran berbagai bentuk madrasah tersebut. Persoalannya adalah: Apakah kehadiran berbagai bentuk madrasah akan mendukung pengembangan Islamisasi Pengetahuan, ataukah justru ada modelmodel lainnya yang hendak dikembangkan, sehingga profilnya akan berbeda dengan yang lain?

${ }^{2}$ Gagasan Madrasah Terpadu muncul setelah melihat Madrasah Model dalam perjalanannya kurang komunikatif dan cenderung individualistik, maka munculah gagasan tentang Madrasah Terpadu, baca, Imran Siregar (ed), Efektifitas Penyelenggaraan Madrasah Terpadu, (Jakarta: Balai Penelitian dan Pengembangan Agama Kemenag RI, 2010), hlm. 3. 
Topik Islamisasi ilmu pengetahuan dan pendidikan dalam Islam sudah diperdebatkan sejak Konferensi Dunia Pertama tentang Pendidikan Islam di Makkah pada 1977. Tetapi sayangnya belum ada usaha serius untuk melacak sejarah gagasan dan mengkaji atau mengevaluasi sejumlah persoalan pokok yang berkenaan dengan topik ini pada tingkat praktis. ${ }^{3}$ Dalam bahasa Arab Islamisasi ilmu disebut sebagai "Islämiyah al-Ma'rifat" dan dalam bahasa Inggris disebut sebagai "Islamization of Knowledge". Dalam Islam, ilmu merupakan perkara yang amat penting, bahkan menuntut ilmu diwajibkan sejak lahir hingga ke liang lahat. Ayat al-Qur'an yang pertama yang diturunkan berkaitan dengan ilmu yaitu surah al-'Alaq ayat 1-5. Menurut ajaran Islam, ilmu tidak bebas nilai-sebagaimana yang dikembangkan ilmuwan Barat akan tetapi sarat nilai, dalam Islam ilmu dipandang universal dan tidak ada pemisahan antara ilmuilmu dalam Islam.

Islamisasi ilmu pengetahuan pada dasarnya adalah suatu respons terhadap krisis masyarakat modern yang disebabkan karena pendidikan Barat yang bertumpu pada suatu pandangan dunia yang lebih bersifat materialistis, sekularistik, relativistis; yang menganggap bahwa pendidikan bukan untuk membuat manusia bijak yakni mengenali dan mengakui posisi masingmasing dalam tertib realitas, akan tapi memandang realitas sebagai sesuatu yang bermakna secara material bagi manusia, dan karena itu hubungan manusia dengan tertib realitas bersifat eksploitatif bukan harmonis. Ini adalah salah satu penyebab penting munculnya krisis dalam modernisasi.

Menurut al-Faruqi Islamisasi pengetahuan adalah menuangkan kembali pengetahuan sebagaimana yang dikehendaki oleh Islam, yaitu dengan memberikan definisi baru, mengatur data, mengevaluasi kembali kesimpulan-kesimpulan dan memproyeksikan kembali tujuan-tujuannya. ${ }^{4}$ Sementara al-Atțas mengatakan bahwa Islamisasi pengetahuan adalah sebagai proses pembebasan atau pemerdekaan. Sebab ia melibatkan pembebasan roh manusia yang mempunyai pengaruh atas jasmaninya dan proses ini menim-

${ }^{3}$ Wan Mohd Nor Wan Daud, Filsafat dan Praktik Pendidikan Islam Syed M. Naquib Al-Attas, (Bandung: Mizan, 2003), hlm. 23.

4 Ismail R. al-Faruqi, Islamisasi Pengetahuan, (Bandung: Balai Pustaka, 1984), hlm. 98. 
bulkan keharmonisan dan kedamaian dalam dirinya, sebagai fitrahnya. $^{5}$

Mencermati konsep tentang Islamisasi pengetahuan di atas, dapat ditarik kesimpulan bahwa gagasan Islamisasi sebenarnya berangkat dari asumsi, bahwa ilmu pengetahuan itu tidak bebas nilai atau netral. Memang, diakui pentingnya transfer ilmu Barat ke Dunia Islam, ilmu itu secara tak terelakkan sesungguhnya mengandung nilai-nilai dan merefleksikan pandangan dunia masyarakat yang menghasilkannya, dalam hal ini masyarakat Barat. Sebelum diajarkan lewat pendidikan, ilmu tersebut harus ditapis terlebih Dahulu agar nilai-nilai yang bertentangan secara diametral dengan pandangan dunia Islam bisa disingkirkan. Gagasan Islamisasi, dengan demikian, merupakan upaya dekonstruksi terhadap ilmu pengetahuan Barat untuk kemudian direkonstruksi ke dalam sistem pengetahuan Islam. ${ }^{6}$

Islamisasi ilmu pengetahuan mencoba mencari akar-akar krisis tersebut. Akar-akar krisis itu di antaranya dapat ditemukan di dalam ilmu pengetahuan, yakni konsepsi atau asumsi tentang realitas yang dualis, sekularis, revolusioneris, dan karena itu pada dasarnya bersifat realitivitas dan nihil. Islamisasi ilmu pengetahuan adalah suatu upaya pembebasan pengetahuan dari asumsi-asumsi atau penafsiran-penafsiran Barat terhadap realitas, dan kemudian menggantikannya dengan pandangan dunia Islam. ${ }^{7}$

Berkaitan dengan keprihatinan pengaruh sains Barat modern, para pembaharu pemikir pendidikan Islam mencoba kembali menggagas konsep Islamisasi sains sekaligus menjadikan Islam sebagai paradigma ilmu pengetahuan. Mereka berupaya membersihkan pemikiran-pemikiran Muslim dari pengaruh negatif kaidahkaidah berfikir ala sains modern, sehingga pemikiran Muslim benar-benar steril dari konsep sekuler. Al-Atțas mengatakan, bahwa Islamisasi ilmu berarti pembebasan ilmu dari penafsiran-penafsiran yang didasarkan pada ideologi sekuler, dan dari makna-makna serta ungkapan-ungkapan manusia sekuler. ${ }^{8}$

${ }^{5}$ S.M. Naquib Al Attas, The Consept OF Education in Islam, (Kualalumpur: ISTAC), hlm. 43.

${ }^{6}$ Wan Mohd Nor Wan Daud, Filsafat dan Praktik Pendidikan Islam Syed M. Naquib Al-Attas, hlm. 23.

${ }^{7}$ Al Attas, The Concept of Education ..., hlm. 88.

${ }^{8}$ Mujamil Qomar, Epistemologi Pendidikan Islam dari Metode Rasional hingga Metode Kritik, (Erlangga: Jakarta, 2005), hlm. 116. 
Banyak pemahaman ilmu pengetahuan yang terlanjur tersekulerkan dapat digeser dan diganti dengan pemahaman-pemahaman yang mengacu pada pesan-pesan Islam, manakala "proyek Islamisasi pengetahuan" benar-benar digarap secara serius dan maksimal. Sebagai tindak lanjut dari gagasan-gagasan normatif itu, para pemikir Muslim harus berupaya keras merumuskan kembali Islamisasi pengetahuan secara teoritis dan konseptual yang didasarkan pada gabungan antara argumentasi rasional dan petunjuk-petunjuk wahyu agar konstruksi epistemologi pendidikan Islam sesuai dengan tuntutan zaman.

\section{Islamisasi Pengetahuan dan Implikasinya terhadap Pengembangan Madrasah}

Dari dua gagasan tentang Islamisasi pengetahuan yang dijelaskan di bagian depan, dapat digarisbawahi bahwa Islamisasi pengetahuan lebih melihat pemikiran dan pandangan nonmuslim, terutama pandangan ilmuwan Barat, sebagai ancaman yang sangat dominan dan orang-orang Islam harus berlindung menyelamatkan identitas dan otentisitas ajaran agamanya.

Karena itu, ia cenderung menggali teks dalam rangka mengendalikan perubahan sosial, dan perlu merumuskan ukuranukuran normatif di bidang pengetahuan agar ditemukan corak yang lebih "khas Islam". Islamisasi pengetahuan berarti mengislamkan atau melakukan penyucian terhadap ilmu pengetahuan produk nonmuslim (Barat) yang selama ini dikembangkan dan dijadikan acuan dalam wacana pengembangan sistem pendidikan Islam, agar diperoleh ilmu pengetahuan yang bercorak "khas Islami".

Namun demikian, dengan tanpa berpretensi untuk mengecilkan arti gagasan besar dari kedua tokoh tersebut di atas, agaknya gagasan itu cukup menarik untuk dikritisi ulang dan dikembangkan wawasan dan kawasannya di saat umat Islam telah memasuki era globalisasi dan perubahan sosial yang begitu cepat. Bukankah paradigma tersebut lebih bersifat reaktif dari pada proaktif? Jika sudah ditemukan ciri khasnya yang Islami, kemudian hendak dibawa ke mana? Jangan-jangan ciri khas Islami itu menjadi sesuatu yang standar, baku, absolut, konstan dan rutin, sehingga seolah-olah tidak ada peluang dan gerak yang dinamis. Jika ciri khas Islami itu dipandang sebagai sesuatu yang relatif dan dinamis, maka pertanyaan berikutnya akan segera muncul 
"bukankah umat Islam hanya terjebak dalam pencarian kerangka Islami, dan kurang memiliki kesempatan untuk berobsesi dalam penggalian dan pengembangan IPTEK'? Selama ini ternyata umat Islam masih berada dalam pencarian konsep, kerangka dan paradigma Islamisasi pengetahuan.

Menurut asumsi penulis, sikap tersebut agaknya kurang efektif untuk mengantisipasi era globalisasi, justru umat Islam akan terhambat oleh akselerasi perkembangan dan kemajuan Iptek serta cepatnya arus perubahan sosial. Kiranya cukup menarik untuk dicermati sebuah kritik tajam yang pernah dilontarkan oleh kedua orang orientalis kenamaan, yaitu Ernes Renan (Prancis) dan William Muir (Inggris), yang mengemukakan bahwa "keterbelakangan umat Islam adalah karena peradabannya inferior (berkualitas rendah), dan ini terkait dengan agama mereka yang inferior. ${ }^{9}$

Kritik tersebut merupakan masukan sekaligus tantangan bagi umat Islam untuk tidak mudah terjebak dalam sikap apologis, romantis, dan truth claim dalam menghadapi persoalan Keislaman yang sebenarnya masih berada dalam wilayah ijtihad. Berbagai masukan dan tantangan akan mendorong umat Islam melakukan kebangkitan kembali, melakukan kritik internal, interpretasi kembali terhadap berbagai konsep Islamisasi pengetahuan, sehingga terciptanya keseimbangan antara ketiga dimensi Keislaman (dimensi ideal, interpretasi, dan sejarah). ${ }^{10}$

Islamisasi pengetahuan telah membawa implikasi yang serius terhadap modernisasi Pendidikan Islam termasuk madrasah, yakni pada pola pembaharuan pendidikan yang dijalankan oleh umat Islam. ${ }^{11}$ Berdasarkan dua gagasan tentang Islamisasi pengetahuan di atas, setidaknya ada tiga model Islamisasi pengetahuan yang dapat dikembangkan dalam pembaharuan madrasah yaitu, model purifikasi, model modernisasi, dan model neo-modernis.

Model Purifikasi mengandung arti pembersihan atau penyucian. Dalam arti, ia berusaha menyelenggarakan penyucian ilmu pengetahuan agar sesuai, sejalan dan tidak bertentangan dengan

${ }^{9}$ Mudjia Rahardjo, Quo Vadis Pendidikan Islam, Pembacaan Realitas Pendidikan Islam, Sosial dan Keagamaan, (Malang: UIN Malang Press, 2006), hlm. 223.

${ }^{10}$ Muhaimin, Nuansa Baru Pendidikan Islam, Mengurai Benang Kusut Dunia Pendidikan, (Jakarta: Rajawali Press, 2006), hlm. 42.

11 Zurqoni \& Mukhibat, Menggali Islam Membumikan Pendidikan, Upaya Membuka Wawasan Keislaman \& Pemberdayaan Pendidikan Islam, cet. II (Yogyakarta: Ar-Ruzzmedia, 2013), hlm. 43. 
nilai dan norma Islam. ${ }^{12}$ Model purifikasi berasumsi bahwa dilihat dari dimensi normatif-teologis, doktrin Islam mengajarkan umatnya untuk masuk Islam secara menyeluruh (kaffah) sebagai lawan dari parsial. Dalam al-Qur'an secara apriori menggarisbawahi terwadahinya berbagai aspek kehidupan dalam Islam. ${ }^{13}$ Pandangan ini mempunyai makna bahwa setiap ilmuwan muslim dituntut menjadi aktor beragama yang loyal, concern dan commit dalam menjaga dan memelihara ajaran dan nilai-nilai Islam dalam segala aspek kehidupan. Gagasan al- Faruqi dan al-Attas tentang "Islamisasi Pengetahuan" dapat dikategorikan ke dalam model purifikasi, hal ini dapat dilihat dari empat rencana kerja Islamisasi pengetahuan: 1) penguasaan khazanah ilmu-ilmu Keislaman; 2) penguasaan ilmu-ilmu masa kini; 3) identifikasi kelemahan ilmuilmu umum dalam kaitannya dengan ideal Islam; 4) rekonstruksi ilmu-ilmu umum sehingga menjadi selaras dengan wawasan dan ideal Islam.

Model Modernisasi Islam. Model ini berangkat dari kepedulian akan keterbelakangan umat Islam di dunia sekarang, yang disebabkan oleh sempitnya berpikir, kebodohan, dan eksklusivitas dalam memahami ajaran Islam. Model ini pada dasarnya mengarah pada upaya perbaikan masyarakat muslim dalam cakupan yang luas, terutama menyangkut perubahan pola pikir dan praktek Keislaman. ${ }^{14}$ Jadi makna Islamisasi pengetahuan yang ditawarkan oleh model modernisasi Islam dalam membangun semangat umat Islam untuk selalu modern, maju, progresif, terus menerus melakukan perbaikan dalam berbagai aspek kehidupan agar terhindar dari keterbelakangan dan ketertinggalan di bidang IPTEK.

Adapun keberhasilan pembaharuan pendidikan Islam yang dilakukan oleh umat Islam secara garis besar dapat dikategorisasikan menjadi tiga. ${ }^{15}$ Pertama, pola pembaharuan dengan berorientasi pada pola pendidikan Barat. ${ }^{16}$ Pola ini pada dasarnya

${ }^{12}$ Muhaimin, Nuansa Baru Pendidikan ..., hlm. 61.

${ }^{13}$ Q.S. al-Baqarah/2: 208.

${ }_{14}$ Zurqoni \& Mukhibat, Menggali Islam Membumikan ..., hlm. 44.

15 Zuhairini, dkk. Sejarah Pendidikan Islam, (Jakarta: Bulan Bintang, 1999), hlm. 117.

${ }^{16}$ Umat Islam zaman klasik pernah mencapai kemajuan karena mereka maju dalam bidang ilmu pengetahuan yang dikembangkannya. Dengan demikian mengambil ilmu pengetahuan Barat Modern sebenarnya mengambil kembali ilmu pengetahuan yang pernah dimiliki umat Islam. Lihat Harun 
berangkat dari pandangan bahwa sumber kekuatan dan kesejahteraan hidup yang dicapai Barat adalah sebagai hasil dari perkembangan ilmu pengetahuan dan teknologi modern yang dicapainya. Karenanya untuk mengembalikan kejayaan Islam, sumber kekuatan dan kesejahteraan tersebut harus dikuasai kembali. Penguasaan tersebut dapat dicapai melalui proses pendidikan dengan mengadakan imitasi pola pendidikan yang dikembangkan oleh Barat. Kedua, pola pembaharuan pendidikan Islam yang berorientasi pada sumber Islam murni. Pembaharuan ini pada dasarnya berpijak dari pandangan bahwa sesungguhnya Islam merupakan sumber bagi kemajuan dan perkembangan ilmu pengetahuan modern. Islam sarat dengan ajaran-ajaran yang pada hakikatnya mengandung potensi untuk membawa kemajuan. Sejarah mencatat bahwa di antara sebab-sebab kemunduran umat Islam adalah karena pelaksanaan ajaran Islam tidak sebagaimana mestinya sebagai akibat masuknya bid'ah dalam ajaran Islam. ${ }^{17}$ Ketiga, pola pembaharuan pendidikan yang berorientasi pada nasionalisme. Pola ini berangkat dari pandangan bahwa kemajuan yang dicapai bangsa-bangsa Barat bermula dari rasa nasionalisme yang dimilikinya, yang kemudian menimbulkan kekuatan-kekuatan politik yang berdiri sendiri.

Neo-Modernis berupaya memahami ajaran dan nilai Islam mendasar yang terkandung dalam al-Qur'an dan al-Hadis dengan mengikutsertakan, mempertimbangkan khazanah intelektual muslim klasik serta mencermati kesulitan-kesulitan dan kemudahan-kemudahan yang ditawarkan oleh dunia ilmu pengetahuan dan teknologi modern. Al-Qur'an difungsikan sebagai moral force yang mendorong inisiasi, kreativitas, dan kecerdasan manusia untuk mendayagunakan segenap sumber daya yang tersedia bagi kemaslahatan hidup dan kemajuan budayanya. ${ }^{18}$

Jargon yang dikumandangkan adalah al-muhafazah ala alqadim aș-salih wa al-akhżu bi al-jadid al-aṣlah. Jargon ini menggarisbawahi perlunya para ilmuwan muslim untuk mendudukkan

Nasution, Pembaharuan Dalam Islam, (Jakarta: Bulan Bintang, 1994), hlm. 75.

${ }^{17}$ Nasution, Pembaharuan Dalam ..., hlm. 72.

18 Mahmud Arif, “Aspek Dialogis al-Qur’an dalam Perspektif Pendidikan: Arti Penting Nilai Pedagogis dan pembacaan Produktif" dalam AlTahrir Jurnal Pemikiran Islam, STAIN Ponorogo, Vol 11, No. 2 November 2011 terakreditasi SK Dikti Nomor: 64a/Dikti/Kep/2010, hlm. 291. 
pemikiran, konsep, teori-teori dan temuan-temuan ilmu pengetahuan dari para ulama terdahulu ataupun dari ilmuwan nonmuslim. Jargon ini menghendaki kegiatan edukasi pendidikan Islam yang masih terjerembab dalam himpitan romantisme historis untuk segera menyelaraskan dengan tuntutan zaman. ${ }^{19}$

\section{Visi Baru Pembaharuan Madrasah: \\ Keislaman, Keilmuan, Kebinekaan}

Perkembangan madrasah di Indonesia agar berbeda dengan negara-negara lain di Asia Tenggara. Madrasah di Indonesia mengalami perkembangan menarik karena integrasinya dengan modernitas. Dukungan politik negara terhadap pendidikan Islam, kesadaran umat Islam sendiri tentang modernitas, dan transisi menuju modernitas yang berlangsung cenderung masif sehingga menyebabkan madrasah di Indonesia kini muncul sebagai lembaga pendidikan Islam modern. ${ }^{20}$ Madrasah sekarang sudah muncul sebagai lembaga pendidikan Islam modern yang sejajar dengan sekolah umum.

Pasca reposisi madrasah menjadi pendidikan umum menurut UU No. 20 tahun 2003 tentang Sisdiknas, madrasah memegang dua peran sekaligus yakni peran pendidikan agama dan sekaligus pendidikan umum. Di sinilah sesungguhnya kelebihan sekaligus kelemahan madrasah. Jika dua peran ini bisa dimainkan secara baik justru menjadi daya tarik madrasah, namun jika gagal madrasah akan berada dalam tarikan ekstrem antara mempertahankan nilai asasi pesantren mengadopsi perubahan, dan sulit keluar dari lingkaran dikotomi epistemologis-teoritis.

Jalan keluar dari situasi tersebut adalah menuntut adanya implementasi pengembangan model-model Islamisasi pengetahuan dan penegasan visi pendidikan madrasah sehingga madrasah tidak mudah tergoda oleh tarikan ekstrem, tetapi mampu mengelolanya secara responssif dan tuntas. Model-model Islamisasi pengetahuan harus ditempatkan sebagai pemandu bagi madrasah dalam melakukan pengembangan menjadi MA Umum, MAPK, MA

${ }^{19}$ Majid Irsan al-Kailani, Falsafat at-Tarbiyah al-Islamiyyah, (Mekah: Maktabah Hadi, 1988), hlm. 67.

${ }^{20}$ Arief Subhan, "Persepsi Muslim Indonesia Terhadap Madrasah dan Preferensi Sekolah Mengukur dari Survei”, dalam, Paper for The Secon International Symposium on Empowering Madrasah in The Global Context, (Jakarta: Ministry of Religious Affairs of The Republik Indonesia, 2013), hlm. 4. 
Model dan Keterampilan, maupun MA Diniyah yang menjamin konsistensi madrasah dalam konteks perubahan dan dinamika yang terjadi secara terus menerus. Dengan pengembangan tersebut kerangka visi madrasah akan dapat dibangun dengan mempertimbangkan sumber/nilai Islam, Karakter esensial sejarah madrasah, dan rumusan tantangan masa depan. Kerangka visi tersebut sesuai dengan cita-cita umat Islam Indonesia, yakni adanya lembaga pendidikan yang mampu menyiapkan calon ulama yang cendekia dan cendekia yang ulama.

\section{Keislaman}

Ajaran Islam dengan jelas menunjukkan adanya hubungan organik antara ilmu dan iman. Hubungan organik itu kemudian dibuktikan dalam sejarah Islam klasik Ketika kaum muslimin memiliki jiwa kosmopolit yang sejati. Atas dasar kosmopolitanisme itu umat Islam membangun peradaban dalam arti sebenar-benarnya yang juga berdimensi universal. $^{21}$

Namun demikian, setelah menikmati era kesamaan posisi dengan sekolah umum, madrasah dihadapkan pada masalah yang secara faktual cukup mengganggu kredibilitas madrasah sebagai pusat kegiatan pembelajaran agama Islam. Madrasah dianggap belum mampu membekali peserta didik untuk menjadi pribadi yang Islami. Alokasi waktu yang banyak pada pelajaran agama seharusnya memberikan bangunan yang kuat bagi penanaman nilai-nilai ajaran Islam. Tampaknya mata pelajaran agama Islam belum memberikan fondasi yang kuat bagi keimanan dan ketakwaan pada Allah swt. Madrasah pada kenyataannya tidak saja menjadikan lulusannya serba tanggung antara mata pelajaran agama dan umum. Bahkan justru mengantarkan siswa madrasah meninggalkan orientasi tafaquh fi ad-din ke pola pikir yang serba profan dan materialistik. Pembaharuan pada madrasah terkesan potong kompas, yakni ingin langsung memasukkan ilmu-ilmu umum tanpa mempertimbangkan khazanah intelektual muslim dan bangunan budaya masyarakat muslim yang telah terbentuk berabad-abad.

${ }^{21}$ Nurcholis Madjid, Islam Doktrin dan Peradaban, Sebuah Telaah Kritis tentang Masalah Keimanan, Kemanusiaan dan Kemoderna, (Jakarta: Paradima, 1992), hlm. 24. 
Fakta inilah yang mendorong Munawir Sadzali, mengintrodusir sebagai solusi terhadap apa yang disebutnya "krisis ulama" dengan mendirikan MAPK. Visi MAK adalah penguasaan ilmu pengatahuan khusus tentang ajaran agama Islam (tafaquh fi ad-din). ${ }^{22}$ Namun dengan adanya Surat Edaran Dirjen Pendis No. Dj 11/PP.00/ED681/2006 tentang pelaksanaan Standar Isi justru menutup peluang MAK sebagai warisan kekhasan madrasah. Dengan Surat Edaran tersebut pendidikan agama dibatasi sebatas sebagai mata pelajaran agama, ${ }^{23}$ padahal esensi pendidikan di madrasah adalah penanaman akhlak karimah melalui pembelajaran ilmu-ilmu agama yang mencukupi.

Beberapa kelemahan di atas, menjadikan madrasah dalam posisi yang syarat dengan kritikan bahkan ketidakpercayaan akan fungsi dan urgensinya dalam pembangunan moral dan jati diri bangsa oleh sebagian masyarakat. Kritikan tersebut dialamatkan pada dua hal, yaitu: Pertama, materi atau muatan (content), materi ilmu-ilmu Islam dinilai hanya menekankan pada dimensi teologis (dalam Pengertian yang sempit) dan ritual ajaran Islam. Karena dimensi teologis dan ritual tidak diletakkan dalam kekayaan wacana, maka kajian teologis berhenti pada persoalan Ketuhanan yang bersifat mistisantologis tidak berhubungan dengan realitas kehidupan. Iman sebagai kajian utama pendidikan agama, lebih banyak diorientasikan pada upaya mempertahankan akidah.

Jarang sekali keimanan dikaitkan dengan persoalan yang lebih bersifat kontekstual dalam kehidupan manusia. Kepedulian pada kemiskinan, ketidakadilan, kekerasan, dekadensi moral, dianggap bukan bagian dari proses aktualisasi keimanan. Akibatnya, peserta didik secara verbal dapat memahami ajaran Islam, secara terampil melaksanakannya, tetapi kurang menghayati kedalaman maknanya. Kedua, metodologi. Pelaksanaan pembelajaran ilmu-ilmu Keislaman masih terpaku dengan model konvensional layaknya sebagai pengajian yang monolog dan doktrinatif.

22 Depag RI, Satuan Pendidikan Madrasah Aliyah Keagamaan, (Jakarta: Direktorat Jenderal Pembinaan Kelembagaan Agama Islam, 2001), hlm. 8 .

${ }^{23}$ Ahmad, dkk, Spektrum Baru Pendidikan ..., hlm. 15. 
Dalam keadaan demikian, pendidikan lebih merupakan sebagai perambahan dan pengayaan individu pendidik saja.

Padahal, peserta didik yang telah mempunyai potensi agama (sens of religious) atau keinsafan agama, agama perlu dikembangkan dalam keakraban wacana melalui proses perenungan yang dalam dan proses dialogis yang produktif dan kritis. Hal ini disebabkan karena agama merupakan kekuatan yang mampu meresap jauh ke akar pemikiran dan batin setiap umat manusia. ${ }^{24}$ Dalam konteks ini peserta didik dibiarkan melakukan perambahan batin dan intelektual sehingga kelak menemukan dalam dirinya kedewasaan dalam beragama, baik dalam hal afeksi religiusnya maupun dimensi intelektualnya. ${ }^{25}$ Sebagai akibat adanya kelemahan di atas, maka persoalan yang muncul adalah ilmu-ilmu Keislaman kurang terintegrasi pola pikir yang sempit cenderung membuka jarak antara ilmu-ilmu agama Islam dan ilmu umum.

Menyikapi pudarnya nilai-nilai Keislaman dalam pendidikan madrasah, tidak ada salahnya pemerhati, pengelola, pendamping madrasah mencermati kritikan Nurcholis Madjid terhadap sistem pendidikan tradisional Islam. Nurcholis pernah mensinyalir bahwa lembaga pendidikan Islam termasuk madrasah akan membawa Indonesia pada masa yang akan datang itu seperti sosok"santri yang canggih". ${ }^{26}$ Nurcholis mendambakan penampilan Islam modern yang menyerap secara konstruktif dan positif kehidupan modern, namun semuanya dalam nilai-nilai Keislaman. Dalam bahasa sederhana adanya keselarasan antara IPTEK dan Imtaq.

Perpaduan komponen penunjang IPTEK dan Imtaq diupayakan melalui perpaduan sistem pendidikan tradisional dengan modern. Memasukkan sistem pendidikan "baru" dalam madrasah bukan berarti melepaskan yang "lama" itu

${ }^{24}$ Imam Subchi dkk (ed), Mozaik Pemikiran Islam, (Jakarta: Dikti Kemenag RI, 2011), hlm. 233.

${ }^{25}$ Mukhibat "The Role And Challenges Islamic Education For Reshaping The Nation Character" dalam Conference Proceedings Annual International Conference on Islamic Studies (AICIS) XII, IAIN (Surabaya: Sunan Ampel, 2012), hlm. 2839.

${ }^{26}$ Nurcholis Madjid, Dialog Keterbukaan, Artikulasi Nilai Islam dalam Wacana Sosial Politik Kontemporer, (Jakarta: Paramadina, 1998), hlm. 212. 
mesti dibuang. Pengembangan madrasah harus melihat kembali kitab-kitab lama "klasik" untuk menyikapi agar tidak terjadinya kemiskinan intelektual atau kehilangan jejak riwayat intelektualisme Islam. Kitab kuning jangan dipahami jenis apresiasi doktrinal dan dogmatik, melainkan jenis intelektual dan akademik. Selain itu umat Islam secara wajar mengapresiasikan warisan intelektual dari luar Islam sejalan dengan petunjuk al-Qur'an. Sikap demikian mengindikasikan bahwa umat Islam dalam melakukan pembaharuan madrasah tidak meninggalkan Karakter asli madrasah. Dengan cara ini barangkali merupakan salah satu metode untuk mempertahankan jatidiri madrasah dalam konteks modern.

Berbagai bentuk madrasah yang ada sekarang ini, para pengelola dan stakeholder madrasah harus memikirkan kembali bagaimana menempatkan kembali ilmu-ilmu umum ke dalam daerah pengawasan nilai Islam, karena pada prinsipnya, asal mula semua cabang ilmu pengetahuan adalah berpangkal pada ilmu agama, Seperti Ketika para intelektual muslim mampu mengembangkan dan mengislamkan ilmu pengetahuan modern seperti pada masa Islam klasik. Berbagai upaya pengembangan madrasah harus terlebih Dahulu dengan menangkap pesan dalam al-Qur'an. Modernisasi madrasah tidak boleh hanya mempertimbangkan kondisi, tantangan sosio-historis dan kultural yang dihadapi masyarakat muslim kontemporer, tetapi juga harus Memperhatikan muatanmuatan khazanah intelektual muslim era klasik.

2. Keilmuan

Persoalan mendasar yang terjadi hampir merata di dunia pendidikan Islam kontemporer adalah terpisahnya lembagalembaga pendidikan yang memiliki konsentrasi dan orientasi yang berbeda. Sebagian madrasah menitikberatkan orientasinya pada "ilmu-ilmu modern" dan pada sisi lain ada madrasah yang hanya memfokuskan diri pada "ilmu-ilmu tradisional" yang dikenal dengan dualisme pendidikan.

Islamisasi pengetahuan dengan model modernisme pada prinsipnya menghilangkan dualisme pendidikan tersebut. Kedua orientasi kelembagaan tersebut sama-sama memiliki sisi positif yang patut dikembangkan juga mempunyai kelemahan yang sama sekali harus dibuang dan ditinggalkan. Usaha modernisasi tertuju pada upaya untuk 
mengompromikan kedua orientasi kelembagaan tersebut dengan memadukan sisi baik antara keduanya, yang pada gilirannya akan melahirkan sistem pendidikan Islam yang ideal. Usaha ini dapat disebut dengan sistem pendidikan Indonesia menuju ke arah titik temu atau konvergensi dan usaha ini berawal pada perpaduan unsur-unsur keilmuan.

Upaya menghilangkan dualisme pendidikan tersebut tidak terlepas dari usaha menghilangkan dikotomi keilmuan yang ada sekarang. Sebab mengakarnya paham dikotomi keilmuan amat berpengaruh pada pengembangan madrasah. Pada masa kejayaan Islam, hampir tidak terlihat adanya dikotomi keilmuan. $^{27}$ Karena Islam tidak mengajarkan pemisahan ke dalam ilmu agama dan ilmu umum, seluruh ilmu bersumber dari Allah dan harus dipelajari semuanya.

Sejarah pendidikan Islam telah menunjukkan bahwa keseimbangan antara ilmu agama dan ilmu umum terdapat masa kejayaan dan kegemilangan. Perkembangan ilmu pengetahuan berjalan sangat pesat, seperti ilmu agama, bahasa, sejarah,aljabar, fisika, kedokteran. Tokoh-tokoh seperti al-Farabi, Ibnu Sina, Ikhwan al-Shafa sangat menyadari bahwa kesempurnaan manusia hanya akan terwujud dengan penyerasian antara ilmu umum dan agama, sebagai bagian yang tidak terpisahkan dalam komponen keilmuan dalam Islam.

Madrasah sekarang dan ke depan harus dipahami lebih dari sekadar menjalankan peran yang selama ini dialamatkan madrasah, harus menjadi the centre of excellence baik ilmu agama maupun ilmu umum. Artinya upaya pengembangan madrasah harus menuju ke arah titik temu atau konvergensi yakni perpaduan unsur-unsur keilmuan. Usaha demikian dalam rangka merespons perubahan-perubahan yang begitu cepat baik pada tataran konsep maupun praktek. Madrasah tidak bisa lagi mengisolasikan diri dari perubahan-perubahan paradigma, konsep, visi, dan orientasi baru pengembangan pendidikan nasional.

Sudah saatnya diberikan strategi khusus, bagaimana agar madrasah mampu merespons secara tuntas tuntutan masa depan tanpa mengorbankan identitasnya. Menurut Mujamil

27 M. Athiyah al Abrasyi, Dasar-Dasar Pokok Pendidikan Islam, (Jakarta: Bulan Bintang, 1993), hlm. 167-172. 
Qomar dibutuhkan pengelola madrasah secara kreatif dan inovatif yang berani mengambil kebijakan atau memutuskan hal-hal yang berbeda dengan petunjuk formal dari kalangan atas. ${ }^{28}$ Peluang madrasah untuk tampil sebagai lembaga pendidikan yang menjadi pilihan masyarakat sangat mungkin diwujudkan melalui strategi khusus di atas. Namun tentunya madrasah dituntut mampu menunjukkan berbagai keunggulan, yakni: 1) keunggulan kepribadian Islami, keunggulan ini sangat dibutuhkan oleh masyarakat terutama dalam menghadapi budaya barat yang mengglobal. Kepribadian Islami harus dapat dibuktikan oleh siswa atau alumni madrasah melalui keimanan yang tangguh, ketaatan beribadah, akhlak yang mulia, ahli agama, toleransi, terbuka, demokratis, dan lapang dada; 2) keunggulan intelektual/keilmuan, keunggulan ini sangat dibutuhkan masyarakat terutama untuk menghadapi perkembangan IPTEK. Ini harus mampu diwujudkan oleh siswa atau alumni madrasah seperti Prestasi akademik maupun non akademik; 3) keunggulan keterampilan, keunggulan ini sangat dibutuhkan masyarakat seperti mengoperasikan produk-produk teknologi modern, menembus dunia kerja, mempunyai life skill. Ketiga keunggulan tersebut harus menopang satu sama lain untuk membentuk distingsi alumni madrasah.

Untuk mewujudkan keunggulan-keunggulan tersebut di atas, madrasah harus mampu menerjemahkan model neo modernisme baik dalam tataran kurikulum maupun praktek pendidikannya. Model ini tertuju pada upaya memasukkan kurikulum "umum" ke dalam pendidikan madrasah yang telah memiliki kurikulum tersendiri, sehingga yang akan terjadi kombinasi dua bentuk unsur keilmuan dalam sekala yang utuh. Dengan model ini, akan terjadi semacam enlightening keagamaan pada "ilmu-ilmu umum" kemudian mengintegrasikannya ke dalam hirarki keilmuan Islam. Sehingga disadari bahwa ide ini hanya pada tataran filosofis.

Gagasan di atas, seirama dengan acuan operasional penyusunan kurikulum 2013 yakni semua mata pelajaran dapat menunjang peningkatan iman dan takwa serta akhlak mulia. Hal dapat dilihat dalam rumusan Standar Kelulusan

${ }^{28}$ Mujamil Qomar, Manajemen Pendidikan Islam, (Jakarta: Erlangga, 2007), hlm. 97. 
(SKL) dalam kurikulum 2013 yang lebih dikenal dengan Kompetensi Inti. Kompetensi Inti merupakan terjemahan atau operasionalisasi SKL dalam bentuk kualitas yang harus dimiliki mereka yang telah menyelesaikan pendidikan pada satuan pendidikan tertentu atau jenjang pendidikan tertentu, gambaran mengenai kompetensi utama yang dikelompokkan ke dalam aspek sikap, pengetahuan, dan keterampilan (afektif, kognitif, dan psikomotor) yang harus dipelajari peserta didik untuk suatu jenjang sekolah, kelas dan mata pelajaran. Kompetensi Inti harus menggambarkan kualitas yang seimbang antara pencapaian hard skills dan soft skills. ${ }^{29}$

3. Kebhinekaan

MBS adalah model pengelolaan yang mendasarkan pada kekhasan, Karakteristik, kebolehan, kemampuan, dan kebutuhan sekolah. ${ }^{30}$ Dengan batasan seperti ini, maka MBS menjamin adanya kebhinekaan/keberagaman dalam mengelola sekolah asal tetap dalam koridor kebijakan pendidikan nasional. Tidak ada lagi penekanan pada keseragaman seperti yang selama ini terjadi telah mematikan kreativitas pengelolaan dan pengembangan madrasah sekaligus bertentangan dengan watak populis madrasah.

Pengembangan terhadap madrasah harus didorong munculnya berbagai bentuk, tipe, model, dan pendekatan pendidikan yang bervariasi sesuai dengan kompleksitas masyarakat. Dengan aneka ragam tipe akan memberikan banyak pilihan bagi masyarakat muslim untuk mensekolahkan anak-anaknya sesuai dengan keinginannya. Berbagai program dampingan terhadap madrasah harus memberi ruang tumbuh yang wajar bagi aspirasi umat Islam.

Namun yang perlu diperhatikan dalam program pengembangan ataupun pemberdayaan madrasah, harus diarahkan untuk menciptakan suatu lembaga pendidikan yang mempunyai identitas kultural, yang lebih sejati sebagai konsep pendidikan masyarakat Indonesia baru yang bercirikan keaslian Indonesia. Artinya Ketika madrasah telah dimodeniasi tetapi gagal memahami masa lalu, maka yang terjadi adalah

${ }^{29}$ Kementerian Pendidikan dan Kebudayaan, Kurikulum 2013, (Jakarta: Kemdikbud RI, 2013), hlm. 8.

${ }^{30}$ Slamet, Desentralisasi Pendidikan di Indonesia, (Jakarta: Depdiknas, 2008), hlm. 3. 
kemiskinan intelektual. Maka berbagai usaha pemberdayaan dan pengembangan madrasah perlu mempertahankan Karakter asasi pesantren yang ditunjang dengan upaya internalisasi unsur-unsur keilmuan modern dan tujuan-tujuan pragmatis yang ingin dicapai.

\section{E. Penutup}

Sebagai upaya inovasi dalam Sistem Pendidikan Islam, madrasah tidak lepas dari berbagai problema yang dihadapi, antara lain: Pertama, banyak Madrasah Binaan STAIN Ponorogo telah kehilangan akar sejarahnya, sehingga keberadaan madrasah bukan merupakan kelanjutan pesantren. Kedua, munculnya dualisme pemaknaan terhadap madrasah. Madrasah diidentikkan dengan sekolah karena memiliki muatan secara kurikulum yang relatif sama dengan sekolah umum. Di sisi lain, madrasah dianggap sebagai pesantren dengan sistem klasikal. Diakui bahwa model pendidikan madrasah di dalam perundang-undangan negara, memunculkan dualisme sistem pendidikan yang belum dapat diselesaikan sampai sekarang. Dualisme ini tidak hanya berkenaan dengan sistem pengajarannya tetapi juga menjurus pada keilmuannya. Pola pikir yang sempit cenderung membuka jarak antara ilmu-ilmu agama Islam dan ilmu-ilmu umum.

Redefinisi Islamisasi pengetahuan merupakan respons terhadap dikotomi di atas dan sebagai jalan keluar untuk menjadikan madrasah sebagai pendidikan konvergen dengan kurikulum terpadu antara ilmu agama dan ilmu umum. Setidaknya ada tiga model Islamisasi pengetahuan yang dapat dikembangkan dalam pengembangan dan pemberdayaan madrasah, yaitu model purifikasi, model modernisasi, dan model neo-modernisme Islam. Model-model tersebut akan mengarah pada madrasah yang berkarakter Keislaman, keilmuan, dan kebhinekaan. Keislaman, model purifikasi menghendaki bahwa pengembangan madrasah harus melihat kembali kitab-kitab lama "klasik" untuk menyikapi agar tidak terjadinya kemiskinan intelektual atau kehilangan jejak riwayat intelektualisme Islam. Keilmuan, modernisasi madrasah harus menuju ke arah titik temu atau konvergensi yakni perpaduan unsur-unsur keilmuan. Kebhinekaan, pengembangan terhadap madrasah harus didorong munculnya berbagai bentuk, tipe, model, dan pendekatan pendidikan yang bervariasi sesuai dengan kompleksitas masyarakatnya. 


\section{Kepustakaan}

Ahmad, Nunu, dkk, Spektrum Baru Pendidikan Madrasah, Jakarta: Puslitbang Kemenag RI, 2010.

Ahid, Nur, Problematika Madrasah Aliyah di Indonesia, Kediri: STAIN Kediri Press, 2009.

Al Attas, S.M. Naquib, The Consept OF Education In Islam, Kualalumpur: ISTAC, 1991.

Al-Abrasyi, M. Athiyah, Dasar-Dasar Pokok Pendidikan Islam, terj. Jakarta: Bulan Bintang, 1993.

Al-Faruqi, Ismail R, Islamisasi Pengetahuan, Balai Pustaka: Bandung, 1984.

A-Kailani, Majid Irsan, Falsafat al Tarbiyah al Islamiyyah, Mekah, Maktabah Hadi, 1988.

Arif, Mahmud, "Aspek Dialogis al-Qur'an dalam Perspektif Pendidikan: Arti Penting Nilai Pedagogis dan pembacaan Produktif" dalam Al-Tahrir Jurnal Pemikiran Islam, STAIN Ponorogo, 2 November 2011 terakreditasi SK Dikti Nomor: 64a/Dikti/Kep/2010, 2011.

Arifi, Ahmad, Politik Pendidikan Islam; Menelusuri Ideologi dan Aktualisasi Pendidikan Islam Di Tengah Arus Globalisasi, Yogyakarta: Teras, 2009.

Depag RI, Satuan Pendidikan Madrasah Aliyah Keagamaan, Jakarta: Direktorat Jenderal Pembinaan Kelembgaan Agama Islam, 2001.

Kementerian Pendidikan dan Kebudayaan, Kurikulum 2013, Jakarta: Kemdikbud RI, 2013.

Madjid,Nurcholis, Islam Doktrin dan Peradaban, Sebuah Telaah Kritis tentang Masalah Keimanan, Kemanusiaan dan Kemoderna, Jakarta: Paradima, 1992.

----. Dialog Keterbukaan, Artikulasi Nilai Islam dalam Wacana SosialPolitik Kontemporer, Jakarta: Paramadina, 1998.

Muhaimin, Nuansa Baru Pendidikan Islam, Mengurai Benang Kusut Dunia Pendidikan, Jakarta: Rajawali Press, 2006.

Mukhibat, "The Role And Challenges Islamic Education For Reshaping The Nation Character" dalamConference Proceedings Annual International Conference on Islamic Studies (AICIS) XII,IAIN Sunan Ampel, Surabaya, 2012.

Mukhibat, Manajemen Berbasis Sekolah (MBS), Membuka Ruang Kreativitas, Inovasi, dan Pemberdayaan Potensi Sekolah 
Melalui Perluasan Peran Serta Masyarakat, Ponorogo, STAIN Po Press, 2012.

Nasution, Harun, Pembaharuan Dalam Islam, Jakarta: Bulan Bintang, 1994.

Qomar, Mujamil Qomar, Manajemen Pendidikan Islam, Jakarta: Erlangga, 2007.

Qomar, Mujamil, Epistemologi Pendidikan Islam dari Metode Rasional hingga Metode Kritik, Erlangga: Jakarta, 2005.

Rahardjo, Mudjia, Quo Vadis Pendidikan Islam, Pembacaan Realitas Pendidikan Islam, Sosial dan Keagamaan, Malang: UIN Malang Press, 2006.

Setiawan, M Nur Kholis (ed), Model Pengembangan Pendidikan

Tinggi, Pengalaman dari Mesir, Singapura, Jerman dan Australia, Jakarta: Diktis Kemenag RI, 2011.

Siregar, Imran (ed), Efektifitas Penyelenggaraan Madrasah Terpadu, Jakarta: Balai Penelitian dan Pengembangan Agama Kemenag RI, 2010.

Slamet, Desentralisasi Pendidikan di Indonesia, Jakarta: Depdiknas, 2008.

Subchi, Imam, dkk (ed), Mozaik Pemikiran Islam, Jakarta: Dikti Kemenag RI, 2011.

Subhan, Arief, "Persepsi Muslim Indonesia Terhadap Madrasah dan Preferensi Sekolah Mengukur dari Survei", dalam, Paper for The Secon International Symposium on Empowering Madrasah in The Global Context, Jakarta: Ministry of Religious Affairs of The Republik Indonesia, 2013.

Wan Daud,Wan Mohd Nor, Filsafat dan Praktek Pendidikan Islam Syed M. Naquib Al-Attas, Bandung: Mizan, 2003.

Zuhairini, dkk, Sejarah Pendidikan Islam, Jakarta: Bulan Bintang, 1999.

Zurqoni \& Mukhibat, Menggali Islam Membumikan Pendidikan, Upaya Membuka Wawasan Keislaman \& Pemberdayaan Pendidikan Islam, Yogyakarta: Ar-Ruzz media, 2013. 
